O. Ugrunovska, PhD (Law), Associate Prof.,

M. Piniashko, Master Student

Ivan Franko National University of Lviv, Lviv, Ukraine

\title{
PROCEEDINGS IN CASES REGARDING THE ESTABLISHMENT OF BIRTH OR DEATH OF A PERSON ON THE TEMPORARILY OCCUPIED TERRITORY OF UKRAINE
}

The article examines the functioning of the judicial procedure for establishing the facts of birth and death on the temporarily occupied territory of Ukraine in terms of its regulation and effectiveness. The authors analyze the procedural nature of the separate proceeding according to national legislation of Ukraine in comparison with legal framework of several foreign states. As a result, it has been stated that the establishment of the above-mentioned legal facts is not the only Ukrainian know-how.

Specific attention has been paid to the issues of juridical technique regarding the determination of participants that can submit an application in order to set a fact of birth or death of a person. In particular, it has been found that Ukrainian legislator does not circumscribe such categories as "persons who can hand in an application" and "applicants". It has been delineated that lodging an application by the applicant's attorney does not substitute the presence of the independent legal interest, which is necessary to become applicant.

In addition, the article explores the process of proving. It has been concluded that the burden of proof rests on the applicant. However, the court is obliged to be an active participant of the proving in order to establish the circumstances of the case, namely: to request evidence, order to carry out expertise etc. The subject-matter of the cases concerning the establishment of facts of birth or death of a person on the temporarily occupied territory of Ukraine comprises, inter alia, the circumstances regarding time and place of birth (death), familial relationships between the applicant and the person who was born (died). Finally, the article examines the enforcement of the "Namibian exception" in the context of the evaluation of the evidence.

Key words: separate proceedings, court decision, occupied territory, "Namibian exception".

Bulletin of Taras Shevchenko National University of Kyiv. Legal Studies, 2020; 3 (114): 59-63

УДК: 349.2

DOI: https:doi.org/10.17721/1728-2195/2020/5.115-12
ISSN 1728-2195

(C) Taras Shevchenko National University of Kyiv, Publishing center "Kyiv University", 2020

А. Федорчук, студ. ОР "Магістр" Київський національний університет імені Тараса Шевченка, Київ, Україна

\section{ОСОБЛИВОСТІ ДОКАЗУВАННЯ У СПРАВАХ ПРО ДИСКРИМІНАЦІЮ У СФЕРІ ПРАЦІ}

Розкрито особливості доказування у справах про дискримінацію у сфері праці. На підставі аналізу спеціальної літератури, чинного законодавства, міжнародних трудових стандартів внесено пропозиції та рекомендації щодо вдосконалення механізму доказування факту дискримінації у сфері праці. Особливу увагу приділено переведенню тягаря доказування та формуванню "презумпції дискримінації", яка полягає в тому, що у певних випадках, за наявності доказів, які обґрунтовують висунуті звинувачення, тягар доказування відсутності дискримінації може бути перенесений на відповідача. Проаналізовано практику Європейського суду з прав людини про дискримінації у сфері праці й висвітлено основні позиції суду щодо встановлення факту дискримінації. Розелянуто нові види доказів у справах про дискримінацію у сфері праці, а саме, метод ситуціаційного тестування. Запропоновано вимоги щодо умов допустимості доказів у справах про дискримінацію у сфері праці. Окремо звернено увагу на позиції Європейського суду справедливості щодо встановлення фокту дискримінації. Також наведено випадки переведення тягаря доказування на відповідача у випадках, установлених законодавством. Охарактеризовано національний механізм доведення факту дискримінації у сфері праці. Проаналізовано стан національного законодавства та міжнародних стандартів щодо механізму доказування у справах про дискримінацію. Розглянуто нормативно-правове забезпечення, механізми імплементації й інституційну основу забезпечення реалізації державної політики у цій сфері. Особливу увагу приділено зарубіжному досвіду Європейського Союзу, зокрема нормотворчим практикам, для вдосконалення національної концепції розвитку антидискримінаційної стратегії держави.

Ключові слова : дискримінація, доказування, тягар доведення, докази, рівність, міжнародні трудові стандарти.

ВСтУп. Забезпечення рівності й недопущення дискримінації відносять до основоположних міжнародних трудових стандартів. Варто звернути увагу на те, що дискримінація може відбуватися на будь-якій стадії розвитку трудових правовідносин, зокрема: під час прийому на роботу; за встановлення умов трудового договору, зокрема оплати праці; за виплати премій, надання "соціального" пакету; у ході притягнення до дисциплінарної та матеріальної відповідальності; у разі переведень і відсторонення від роботи; у випадку просування по службі; за припинення трудових правовідносин тощо. Доказування фракту дискримінації в суді для забезпечення реалізації права на рівність і заборону дискримінації у сфрері праці викликає ряд проблем на практиці.Так, незважаючи на існування нормативно-правової бази для боротьби з дискримінацією, не визначено належним чином механізм доказування дискримінації. 3 огляду на це, дослідження основних положень щодо доказування дискримінації у сфері праці та пошук шляхів підвищення ефективності реалізації права на захист у сучасних умовах $€$ актуальним.

Проблема дискримінації завжди представляла інтерес для науки трудовго права. Питанню заборони дискримінації у трудових правовідносинах присвячені праці таких учених: А. В. Бородіна, І. В. Лагутіна, Д. А. Паньков, П. Д. Пилипенко, С. М. Прилипко, І. С. Сахарук, О. В. Старчук, І. М. Твердовський, О.В.Тищенко та ін.

Метою статті $є$ визначення особливостей процедури доказування факту дискримінації у сфері праці та внесення пропозицій щодо вдосконалення механізму доказування у справах про дискримінацію.

ВИКЛАД ОСНОВНОГО МАТЕРІАЛУ. ПриНциП РіВНОправності у сфері праці забезпечує рівний доступ до праці й рівні можливості щодо реалізації права на працю. Він не допускає проявів дискримінації у сфері праці. Конституція України закріплює положення про те, що громадяни мають рівні конституційні права і свободи та рівні перед законом (ст. 24) [1]. За загальним правилом, яке закріплене у ст. 81 ЦПК України, кожна сторона має довести ті обставини, на які вона посилається як на підставу своїх вимог або заперечень. У справах про дискримінацію позивач зобов'язаний навести фактичні дані, які підтверджують, що дискримінація відбулася. У разі наведення таких даних доказування їх відсутності покладається на відповідача [2]. Зміни до ЦПК були внесені відносно нещодавно та не повною мірою дозволяють захищати трудові права працвників, але вони вдосконалили механізм доказування у справах про дискримінацію. 
Однак, у справах про захист проти дискримінації загальні правила доказування не дозволяють позивачу в суді ефективно відстоювати свої інтереси у справах про дискримінацію, зокрема у трудових відносинах, де мають місце відносини підпорядкованості між працівником і роботодавцем. Труднощі доказування фракту дискримінації викликані тим, що прямих доказів ії вчинення не існує або їх дуже мало. Роботодавець зрідка відкрито висловлює свої погляди і наміри щодо працівника. Іноді він навіть не усвідомлює, що його дії є дискримінацією працівника. Часто проблема доведення факту дискримінації ускладнюється тим, що роботодавець володіє більшою кількістю інформації [3, с. 217].

Тягар доказування вини, безумовно, є ключовим питанням у справах про дискримінацію. Труднощі збору доказів можуть виявитися значною перешкодою в отриманні обґрунтованого і справедливого судового рішення у справах про дискримінацію, прямої або непрямої. Особливо складним є доведення дискримінації у справах, щодо прийому на роботу або просування по роботі, коли працівнику, який претендував на певну посаду, було відмовлено в прийнятті/просуванні, як він вважає, необґрунтовано. Зазвичай, інформацією, що стосується критеріїв відбору, рівня кваліфікації й оцінювання кандидатів, що претендують на певну посаду, володіє роботодавець. Наприклад, Семенівський районний суд Чернігівської області у рішенні по справі № 744/552/16-ц від 9 серпня 2016 р. констатує, що 3 боку відповідача у ході звільнення позивача з роботи проявлено непряму дискримінацію позивача за ознакою інвалідності. Такий висновок випливає з того, що позивачем продемонстровано суду спроможність виконання своїх посадових обов'язків без істотних обмежень, адже за висновками медиків він може працювати на займаній посаді, натомість відповідачем не надано суду доказів, чому він належним чином не забезпечив розумного пристосування робочого місця позивача. Більш того, відповідачем позивач звільнений за те, що той не забезпечив собі сторонню допомогу, що $є$ безсумнівним порушенням вимог ч. 1 ст. 172 Кодексу законів про працю України, адже такий обов'язок за законом покладено на відповідача. Як підкреслив суд, відповідачем не надано доказів, чому він як роботодавець належним чином не забезпечив розумного пристосування робочого місця. Так і має діяти презумпція: роботодавець має довести, чому він не виконав позитивного обов'язку [4].

На думку І. В.Лагутіної, для визнання фракту дискримінації спочатку необхідно встановлення двох обставин. По-перше, це відмінність у ставленні до працівників. Відмінність установлюється порівнянням працівників, які перебувають в однаковому або подібному становищі. Не можна, наприклад, порівнювати працівника з управлінського персоналу і працівника, який працює в цеху, але можна порівняти двох і більше працівників, які мають однакове коло трудових обов'язків і працюють в однакових умовах. По-друге, ця відмінність має бути заснована на заборонених ознаках. Якщо відмінність усередині однієї групи працівників пов'язана 3 діловими, професійними якостями працівника або визначена властивими даному виду праці вимогами, а також обумовлена особливою турботою держави про осіб, які потребують правового захисту, то це не буде вважатись дискримінацією [3, с. 216].

Доказування у справах про дискримінацію в багатьох країнах здійснюють відповідно до концепції перенесення тягаря доказування з позивача на відповідача. у Глобальній доповіді Міжнародної організації праці "Рівність у сорері праці: виклик зберігається" 2011 р., зазначено, що через труднощі у наданні фрактичних да- них для доведення наявності дискримінації в судах, деякі країни перекладають тягар доказування на роботодавця (п. 65).Така практика вже тривалий час застосовується у США, де на законодавчому рівні закріплено презумпцію вини роботодавця щодо застосовування ним дискримінації стосовно особи, яка претендує на отримання роботи, або працівника, який уже уклав трудовий договір. Визнаною ця концепція $є$ і у праві Європейського Союзу та відображена у прецедентному праві. Такі положення закріплені Директивами Ради Європейського Союзу 97/80/€С від 15 грудня 1997 р. про тягар доказування у справах про дискримінацію за ознаками статі, 2000/43/ЄС від 29 червня 2000 р. про реалізацію принципу рівного відношення до людей незалежно від раси чи етнічного походження, 2000/78/ЄС від 15 листопада 2000 р. про встановлення основних правил щодо рівності у ссрері праці та зайнятості тощо [5, с. 398].

Однак у законодавстві окремих країн закладені й інші підходи щодо тягаря доказування у справах про дискримінацію. Так, у Північній Ірландії він лежить на позивачі у разі прямої дискримінації, і на відповідачеві у зв'язку з непрямою дискримінацією; у ПАР відповідач, у разі подання обґрунтованого позову про дискримінацію, повинен довести, що несправедлива дискримінація не мала місця, або, що його дії не ґрунтувались на заборонених підставах. Погоджуємось із пропозицією I. C. Сахарук про те, що у випадках прийому на роботу та звільнення тягар доведення варто покладати на роботодавця, тоді як при тривалих трудових відносинах передбачити його розподіл між роботодавцем і працівником [6, с.160, 170].

Слід зауважити, що тягар доказування у справах про дискримінацію не переноситься на відповідача автоматично. Позивачу недостатньо просто заявити про факт дискримінації. Він зобов'язаний, насамперед, довести, що мало місце нерівне або неналежне ставлення до нього. Тільки після того, як суд вважатиме встановленими обставини, на яких засновані твердження про дискримінацію, тягар доведення переноситься на відповідача [3, с. 218].

На практиці одна з найсерйозніших проблем, що виникають, коли позивач доводить наявність дискримінації під час найму на роботу або у трудовій діяльності, пов'язується $з$ тим, що тягар доказування факту дискримінації лежить на позивачеві, а це може стати непереборною перешкодою для відшкодування завданої шкоди. Якщо в деяких випадках докази можна подати без особливих труднощів (наприклад, у разі подачі оголошень про наявні вакансії, коли ознаки дискримінації можуть бути очевидними), набагато частіше дискримінація включає дію, яка $€$ швидше предметом підозр, аніж установленим фрактом, який важко довести, зокрема, у разі здійснення непрямої й систематичної дискримінації. Більше того, інформація та записи, які становлять письмові докази, зазвичай містяться в руках відповідача. [7, с. 101]. Крім того, у спорах щодо дискримінації під час прийому на роботу до предмета доказування відносять також факти звернення до відповідача для працевлаштування та відмови у прийнятті на роботу. Тому підтримуємо пропозицію необхідності закріплення права особи вимагати оформлення письмової відмови відмови у прийомі на роботу [6, с. 171].

Європейський суд із прав людини виходить із того, що у справах щодо заборони дискримінації заявник має навести факти, які підтверджують, що відмінність у ставленні відбувалася. У справі "Пічкур проти України" від 7 листопада 2013 р., ЄСПЛ, визнавши, що заявник перебував у відносно схожій ситуації з пенсіонерами, які проживали в Україні, щодо самого права на отримання 
пенсії, далі розглядав, чи може бути виправданою різниця у поводженні, на яку заявник скаржиться. У зв'язку із цим суд зазначає, що органи влади не надали ніякого обґрунтування щодо позбавлення заявника його пенсії лише через те, що він проживав за кордоном. Суд зазначає, що Уряд не посилався на міркування щодо міжнародного співробітництва з метою обґрунтування поводження з пенсіонерами, які проживають в Україні, в інший спосіб, ніж із тими, які проживають за кордоном. Підвищення мобільності населення, вищі рівні міжнародного співробітництва й інтеграції, а також розвиток банківського обслуговування й інформаційних технологій більше не виправдовують переважно технічних обмежень щодо осіб, які отримують соціальні виплати, проживаючи за кордоном. Суд визнав порушення ст. 14 Конвенції у поєднанні зі ст. 1 Першого протоколу [8].

В іншій справі "Андрле проти Чеської Республіки" від 17 лютого 2011 р. ЄСПЛ визнав, що відмінне ставлення має правомірну мету. Батько двох дітей скаржився, що для чоловіків, які виховують дітей, на відміну від жінок, не передбачено скорочення пенсійного віку. ЄСПЛ погодився, що це правило переслідує законну мету - компенсувати жінкам фрактичну нерівність і тяготи, спричинені наявністю особливих історичних умов на теренах колишньої Чехословаччини, коли жінки були змушені доглядати дітей, вести домашнє господарство та ще й працювати повний робочий день. Тривалість і обсяг заходів, необхідних для виправлення історичної нерівності, не є очевидно нерозумними, а отже держава не порушила надану їй свободу розсуду в цій сфрері [9, с. 57].

У справах про дискримінацію використовують письмові докази, показання свідків, речові докази, висновки експертів тощо. Перелік допустимих видів доказів може змінюватись у різних країнах. Однак труднощі отримання доказів залишаються серйозною перешкодою для встановлення дискримінації навіть у тих державах, де діє перенесення тягаря доказування. Для вирішення цієї проблеми намагаються розширити коло допустимих видів доказів (тестування, статистичні дані, аудіо- та відеозаписи, анкетування).

Ситуаційне тестування $€$ експериментальним методом із метою встановлення фракту дискримінації, який передбачає навмисне створення ситуації, що дозволяє перевірити, чи піддається людина дискримінації. Навколо особи, потенційно здатної здійснити дискримінувальні дії, створюється ситуація, вона провокується на їх учинення, не підозрюючи, що за нею спостерігають. Така особа "стикається" з підставними "кандидатами", що володіють рядом характеристик, на підставі яких може проводитися дискримінація. Ситуаційні тести дозволяють виявляти випадки прямої дискримінації, які часто приховують за відмовками (такими, наприклад, як "вакансія вже зайнята"). Результат тестування представляється як доказ до суду, часто у формі показань свідків, іноді у вигляді звіту повноважної офріційної особи. Уперше цей метод розроблено вченими-соціологами та використано у Великобританії та США в 1970 рр. [3, с. 219].

У випадках "ситуаційного тестування" особи розуміють або очікують, що зазнають дискримінаційного ставлення. Вони хочуть не стільки отримати послугу, скільки зібрати докази. Це означає, що ці особи не є "жертвами" дискримінації у традиційному розумінні цього поняття. Такі особи мають на меті не відшкодування завданої шкоди, а забезпечення дотримання чинного законодавства. У Швеції розглядалася справа, у якій група студентів проводила ситуаційне тестування в нічних клубах і ресторанах, і Верховний суд визнав, що учасники цієї тестгрупи все одно мають право на судове оскарження дискримінації. Водночас розмір належного їм відшкодування може бути зменшений з огляду на те, що фактично вони не були позбавлені того, що хотіли отримати, наприклад доступу до конкретних закладів. Водночас із метою обмеження можливості подання необґрунтованих позовів щодо дискримінації, потрібно нормативно закріпити необхідність доведення позивачем фрактів, які дозволять у загальному встановити, що мала місце дискримінація [10, с. 137].

Дискримінація майже ніколи не проявляється назовні у відкритий, явний спосіб. Дуже часто підстава відмінного ставлення або взагалі не виявляється назовні, або, на перший погляд, виглядає так, ніби зумовлена іншими обставинами, наприклад індивідуальні пільги, що призначаються за умови виходу на пенсію і пов'язані із захищеною ознакою віку. Цікавою є справа "Центр рівних можливостей і протидії расизму проти фірми "Ферин"'" (Centrumv. FirmaFeryn, 2008), у якій власник бельгійської компанії відкрито (усно і в оголошеннях) заявляв, що не прийматиме на роботу "іммігрантів". Європейський Суд справедливості (далі - ЄСС) визнав, що це явний випадок прямої дискримінації на підставі расового чи етнічного походження. За загальним правилом, саме особа, що подає позовну заяву, повинна переконати відповідний орган, що вона зазнала дискримінації. Відповідно, позови про дискримінацію нерідко базуються на суб'єктивних припущеннях. 3 огляду на те, що держава часто контролює більшість доказів, необхідних для обґрунтування скарги, ЄСПЛ зазвичай аналізує всю сукупність доказів загалом. Тому, якщо наведені заявником факти виглядають переконливо й узгоджуються 3 наявними доказами, ЄСПЛ вважає їх установленими, якщо тільки держава не наведе переконливого спростування цих фактів [10, с. 133].

Згідно з позицією ЄСПЛ, докази можуть ґрунтуватися на співіснуванні достатньо сильних, чітких та узгоджених між собою припущень чи аналогічних неспростовних презумпцій факту. Крім того, рівень переконливості, необхідний для винесення конкретного висновку, та пов'язаний із ним поділ обов'язку доведення по суті пов'язані зі специфікою фактів, природою скарги та правом, порушення якого оскаржується. У справі Бруннхофpep (Brunnhofer) заявниця оскаржувала дискримінацію за ознакою статі: вона отримувала меншу заробітну плату, ніж її колеги чоловічої статі, хоча вони мали однакову зарплатну категорію. ЄСПЛ зазначив, що заявниця має довести, що вона, по-перше, дійсно отримує меншу заробітну плату, ніж ії колеги-чоловіки, і подруге, виконує рівноцінну з ними роботу. Цього вистачить для побудови презумпції, що єдиним поясненням відмінного поводження $€$ її стать. Тоді роботодавець буде зобов'язаний це спростувати [11].

Слід пам'ятати про дві речі. По-перше, умови допустимості доказів визначаються національним законодавством, і ці вимоги можуть бути більш суворими, ніж ті, що застосовує ЄСПЛ . По-друге, переведення обов'язку доведення зазвичай не здійснюється у кримінальних справах, коли від імені держави до відповідальності притягується особа, що вчинила злочин на ґрунті расових упереджень (його ще називають "на ґрунті ненависті"). Сторона, що звинувачується в дискримінаційному поводженні, може спростувати таке звинувачення одним із двох шляхів. Вона може довести, що заявник насправді не перебуває в аналогічній чи подібній ситуації з особою, з якою він себе порівнює, або що відмінність у поводженні базується не на захищених ознаках, а на інших об'єктивних відмінностях. Якщо стороні не вдалося спростувати презумпцію, вона має запропонувати аргументи на захист відмінного 
поводження, які свідчать, що таке поводження є об'єктивно виправданим і пропорційним заходом [3, с. 103].

У наведеній вище справі Бруннхофер ЄСС пояснив, яким чином роботодавець може спростувати презумпцію дискримінації. По-перше, це можна зробити, продемонструвавши, що жінки і чоловіки перебувають у відмінному становищі, оскільки виконують нерівноцінну роботу. Це може бути в тому випадку, коли їхні трудові обов'язки суттєво відрізняються. По-друге, можна довести, що відмінність у розмірі заробітної плати зумовлена іншими об'єктивними обставинами, що не мають відношення до статі особи. Наприклад, чоловік отримує доплату на проїзд, оскільки протягом робочого тижня подорожує на довгі відстані і проживає у готелі [11].

Деякі фрактичні обставини, що нерідко супроводжують випадки дискримінації, наприклад існування упередження чи наміру здійснення дискримінації, насправді не мають жодного значення для кваліфікації діяння як дискримінаційного. Щоб довести наявність дискримінації, достатньо просто продемонструвати відмінне ставлення, в основі якого лежить захищена ознака і яке не може бути об'єктивно виправдане. Це означає, що для доведення фракту дискримінації не потрібно доводити окремі факти, що супроводжують випадки дискримінації.

Щодо випадків дискримінації за ознакою раси, то $€ С C$ установив, що не потрібно вказувати на конкретну потерпілу особу. Можна припустити, що за аналогічних обставин цей підхід застосовуватиметься до дискримінації за іншими ознаками. Тоді, як право $€ C$ може звільняти від обов'язку вказувати на конкретну потерпілу від дискримінації особу, це правило не розповсюджується на звернення до ЄСПЛ, оскільки така заява не відповідатиме вимогам її прийнятності за ст. 34 Конвенції. У справі Ферин (Feryn) неможливо було встановити, що хтось намагався влаштуватися на роботу, і йому відмовили; також неможливо було знайти когось, хто міг би сказати, що він вирішив не подаватися на цю роботу через текст оголошення. Іншими словами, у цьому випадку не було осіб, яких можна було б назвати "жертвами дискримінації", а позивачем у справі виступив бельгійський орган із питань рівності. ЄСС зазначив, що не обов'язково називати конкретну особу, що зазнала дискримінації, оскільки і так зрозуміло, що оголошення сформульовано таким чином, що "темношкірі" не намагатимуться влаштуватися на таку роботу, оскільки заздалегідь боятимуться відмови [10, с. 135].

ВИСНОВКИ. Усе викладене вище дозволяє зробити висновки про важливість проведення подальших досліджень у науці трудового права, спрямованих на вироблення єдиного механізму доказування дискримінації у сфрері праці у суді. Необхідно, на наше переконання, у процесуальних кодексах виділити окрему главу щодо основних видів доказів, умов їх допустимості, належності,достатності й достовірності. Важливо врахувати також досвід країн ЄС і США щодо можливості проведення ситуаційних тестів і використання статистичних даних у випадках, коли інші докази відсутні. У процесуальному законодавстві передбачити чіткі умови допустимості доказів, і ці вимоги можуть бути суворішими, ніж ті, що застосовує ЄСПЛ та передбачити неможливість переведення обов'язку доведення у кримінальних справах, коли від імені держави до відповідальності притягується особа, що вчинила злочин на ґрунті расових упереджень.
Список використаних джерел

1. Конституція України від 28.06.1996 року. URL: http://zakon0.rada.gov.ua/laws/show/254\%D0\%BA/96-\%D0\%B2\%D1\%80 (дата звернення: 01.11.2020).

2. Цивільний процесуальний кодекс України від 18.03.2004 p. URL: https://zakon.rada.gov.ua/laws/card/1618-15 (дата звернення: 01.11.2020).

3. Лагутіна І. В. Доказування у справах про дискримінацію у сфері праці / І. В. Лагутіна // Науковий журн. "Правова держава". - 2013. № 16 . - C. 215-221.

4. Рішення Семенівського районного суду Чернігівської області по справі № 744/552/16-ц від 9.08.2016 р. URL: https://reyestr.court.gov.ua/ Review/59673547 (дата звернення: 01.11.2020).

5. Сахарук І. С. Вдосконалення правових механізмів захисту від дискримінації у сфері праці. Науково-практич. юрид. журн. "Публічне право". - 2012. - № 3 (7). - С. 396-404

6. Сахарук I. C. Недопущення дискримінації у ссрері праці як принцип трудового права: дис. ... канд. юрид. наук: 12.00 .05 I. С. Сахарук. - К. , 2012. -230 c.

7. Лагутіна І. В. Тягар доказування вини як ключове питання в справах про дискримінацію у сфері праці / І. В. Лагутіна // Вісник Запорізького нац. ун-ту. Юридичні науки. - 2015. - № 3. - С. 98-105.

8. Справа "Пічкур проти України" від 07.02.2014 p. URL: https://zakon.rada.gov.ua/laws/show/974_984\#Text (дата звернення: 01.11.2020)

9. Порадник із запобігання та протидії дискримінації. URL: https://rm.coe.int/non-discrimination-guidebook-final/16808cb2e1 (дата звернення: 01.11.2020).

10. Посібник з європейського антидискримінаційного права. URL: https://www.echr.coe.int/Documents/Handbook_non_discri_law_UKR.pdf (дата звернення: 01.11.2020).

11. Susanna Brunnhofer v. Bank der österreichischen Postsparkasse AG URL:https://eur-lex.europa.eu/legal-content/EN/TXT/?uri=CELEX\%3A 61999CJ0381 (дата звернення: 01.09.2020)

\section{References}

1. Konstytucija Ukrai'ny vid 28.06.1996 roku URL: http://zakon0.rada.gov.ua/laws/show/254\%D0\%BA/96-\%D0\%B2\%D1\%80 (in Ukrainian)

2. Cyvil'nyj procesual'nyj kodeks Ukrai'ny vid 18.03.2004 r. URL: https://zakon.rada.gov.ua/laws/card/1618-15_(in Ukrainian)

3. Lagutina I. V. Dokazuvannja u spravah pro dyskryminaciju u sferi praci. [Proving the in cases of discrimination in employment.] Naukovyj zhurnal "Pravova derzhava". 2013. № 16. C. 215-221. (in Ukrainian)

4. Rishennja Semenivs'kogo rajonnogo sudu Chernigivs'koi' oblasti po spravi № 744/552/16-c vid 9.08.2016 URL: https://reyestr.court.gov.ua/ Review/59673547 (in Ukrainian)

5. Sakharuk I.S. Vdoskonalennja pravovyh mehanizmiv zahystu vid dyskryminacii' u sferi praci [Improving legal mechanisms for protection against discrimination in the field of labor] Naukovo-praktychnyj jurydychnyj zhurnal "Publichne pravo".2012. № 3 (7). S.396-404. (in Ukrainian).

6. Sakharuk I.S. Nedopushhennja dyskryminacii' u sferi praci jak pryncyp trudovogo prava [Prevention of discrimination in the field of labor as a principle of labor law]: dys. kand. juryd. nauk: 12.00.05. K., 2012. $230 \mathrm{~s}$.

7. Lagutina I. V. Tjagar dokazuvannja vyny jak kljuchove pytannja $v$ spravah pro dyskryminaciju u sferi praci [The burden of proof as a key issue in cases of discrimination in employment]. Naukovyj zhurnal "Pravova derzhava". 2013. №16. S. 215-221. (in Ukrainian)

8. Sprava "Pichkur proty Ukrai'ny" vid 07.02.2014 r. URL: https://zakon.rada.gov.ua/laws/show/974_984\#Texthttps://zakon.rada.gov.u a/laws/show/974 984\#Text (in Ukrainian)

9. Poradnyk iz zapobigannja ta protydii' dyskryminacii' [Adviser on preventing and combating discrimination]. URL: https://rm.coe.int/nondiscrimination-guidebook-final/16808cb2e1 (in Ukrainian)

10. Posibnyk z jevropejs'kogo antydyskryminacijnogo prava [Handbook on European anti-discrimination law]. URL: https://www.echr.coe.int/ Documents/Handbook_non_discri_law_UKR.pdf (in Ukrainian)

11. Susanna Brunnhofer $v$. Bank der österreichischen Postsparkasse AG URL:https://eur-lex.europa.eu/legal-content/EN/TXT/?uri=CELEX\%3A 61999CJ0381_(in Ukrainian)

Наукове дослідження проведено в рамках держбюджетної теми № 19БФ042-01M "Соціально-правові засади збереження та розвитку трудового потенціалу України"

Received: $02 / 09 / 2020$

1st revision: $20 / 10 / 2020$

Accepted: $15 / 11 / 2020$ 
A. Fedorchuk, Master Student

Taras Shevchenko National Univercity of Kyiv, Kyiv, Ukraine

\section{PROOVING IN CASES OF DISCRIMINATION IN THE FIELD OF LABOUR}

This article reveals the particularities of proof in cases of discrimination in the field of labour. On the basis of the analyzed special literature, legislation in force, international labour standards and positive legislative experience of foreign countries, specific proposals and recommendations on the improvement of proof mechanisms are made. Special attention is paid to the shift of the burden of proof and the formation of the "presumption of discrimination" concept, saying that in certain cases, when there is evidence prima facie justifying the allegations, the burden of proving the absence of discrimination can be shifted to the employer. It is determined that in order to recognize the fact of discrimination, it is first necessary to establish two circumstances. First, there is the difference in attitude towards employees. Second, this distinction must be based on prohibited features. The case law of the European Court of Human Rights on discrimination in the field of labor is analyzed and the main positions of the court on establishing the fact of discrimination are highlighted. Types of evidence in cases of discrimination in the field of labor are considered. In cases of discrimination, written evidence, testimony of witnesses, physical evidence, expert opinions, etc. are used. The list of admissible types of evidence may vary from country to country. To solve this problem, it is proposed to expand the range of admissible types of evidence (testing, statistics, audio and video recordings, questionnaires). Requirements for the conditions of admissibility of evidence in cases of discrimination in the field of labor are proposed. Special attention is paid to the position of the European Court of Justice. The article also describes the national mechanism for proving discrimination in the field of labor. It is also proposed to amend national legislation to improve the mechanism for proving discrimination.

Key words: discrimination, proof, burden of proof, evidence, equality, international labor standards.

Bulletin of Taras Shevchenko National University of Kyiv. Legal Studies, 2020; 3 (114): 63-68

удк: 342.95

DOI: https:doi.org/10.17721/1728-2195/2020/5.115-13
ISSN 1728-2195

(C) Taras Shevchenko National University of Kyiv, Publishing center "Kyiv University", 2020

К. Яблуновська, асп. ORCID ID: 0000-0002-5553-2480

Київський національний університет імені Тараса Шевченка, Київ, Україна

\section{ЄВРОПЕЙСЬКІ СТАНДАРТИ ПРАВА НА СВОБОДУ ПЕРЕСУВАННЯ ТА ПРАВА НА ВІЛЬНИЙ ВИБІР МІСЦЯ ПРОЖИВАННЯ}

Статтю присвячено визначенню системи стандартів права на свободу пересування та права на вільний вибір місця проживання, чинних в Європейському Союзі.

У дослідженні використано широкий спектр загальнонаукових та спеціально-юридичних методів і прийомів наукового пізнання, зокрема: порівняльно-правовий, системно-структурний $і$ формально-догматичний методи, а також такі прийоми наукового пізнання, як аналіз і синтез, індукція та дедукція, класифікація тощо.

Унаслідок виконаного дослідження автором обгрунтовано наукову позицію про те, що наявна в Україні система стандартів права на свободу пересування та права на вільний вибір місия проживання лише частково відповідає стандартам прав, які існують у країнах-членах ЄС. Відмінність цих стандартів виявляється на рівні специфріки правового регулювання реалізації названих прав людини у членів сімї громадян країн-членів $€ С$, а також цілей для впровадження відповідних стандартів.

Приведення українських стандартів названих прав людини у відповідність до європейських аналогів передбачає нормотворчу діяльність публічної адміністрації. Джерелом такої нормотворчої роботи має стати базова Директива Європейського Парламенту та Ради 2004/38/ЄС "Про право громадян Союзу та членів їхніх сімей вільно пересуватися та проживати на території держав-членів, яка змінює Регламент 1612/68/ЄЕС та відміняє директиви 64/221/ЄEC, 68/360/ЄEC, 72/194/EEC, 73/148/ ЄEC, 75/34/ ЄEC, 75/35/ GEC, 90/364/ GEC, 90/365/ GEC ma 93/96/ ЄEC" (2004 p.).

Ефективність приведення українських стандартів права на свободу пересування та права на вільний вибір місця проживання до єөропейських аналогів значно підвищиться, якщо публічна адміністрація матиме еталони для відповідного правового регулювання. На наш погляд, таким еталоном можна вважати Allgemeine Verwaltungsvorschrift zum Freizügigkeitsgesetz/EU (AVV zum FreizügG/EU) (Загальне адміністративне уложення Закону про свободу пересування громадян), що створене відповідно до вказаної Директиви ЄС та інших юридичних актів ЄС, які регулюють свободу пересування та права на вільний вибір місця проживання на території Європейського Союзу.

Ключові слова: свобода пересування, вільний вибір місця проживання, права людини, стандарти, законодавство.

ВСтУП. Підписання Україною Угоди про асоціацію між Україною, з однієї сторони, та Європейським Союзом, Європейським співтовариством з атомної енергії та їхніми державами-членами, з іншої сторони [1], проголошення на рівні Основного Закону незворотності європейського курсу України [2] передбачає виконання українською стороною вимог, що $є$ передумовами набуття нею повноправного членства в Європейському Союзі. Однією з неодмінних умов такого членства $€$ адаптація законодавства України до законодавства Європейського Союзу. Для України це означає приведення власної правової системи у відповідність до асquis communautaire, тобто правової системи Європейського Союзу. Причому такий процес стосується не тільки тих юридичних актів $Є С$, які визначені у Додатках до Угоди про асоціацію. Звичайно, він охоплює всі юридичні акти ЄС, які $€$ обов'язковими для всіх країн-членів Європейського Союзу, зокрема й ті, що визначають європейські стандарти права на свободу пересування та права на вільний вибір місця проживання.
Водночас не варто забувати того, що нині юридичні акти $€ C$, зокрема регламенти $€ С$, директиви $€ С$ тощо відіграють виключно роль орієнтира для правотворчості суб'єктів публічної влади і насамперед для суб'єктів публічної адміністрації.

Однак євроінтеграційні прагнення України, подальший рух нашої країни до повноправного членства в ЄС обов'язково приведуть до необхідності адаптації законодавства України до законодавства ЄС й у частині стандартів права на свободу пересування та права на вільний вибір місця проживання, які втілені на рівні спеціальних директив ЄС і регламентів ЄС. Зважаючи на це, необхідно з'ясувати, які стандарти права на свободу пересування та права на вільний вибір місця проживання існують в Європі, а також те, якою мірою наявні в Україні стандарти названих прав людини відповідають цим стандартам. З'ясуванню цього питання i присвячено цю статтю.

Методологічною основою $€$ передусім порівняльноправовий метод дослідження, що дав змогу порівняти 